\title{
Vývoj cen nemovitostí od nabídky do uskutečnění transakce
}

\author{
The Development of The Asking Price Until the Market Price \\ on Real Estate Market Segments
}

\author{
Tereza Opálková*, Martin Cupal \\ Vysoké učeni technické v Brně, Ústav soudniho inženýrství
}

\begin{abstract}
Abstrakt
Článek se zabývá sledováním nabídkových cen až do realizace tržní transakce jako ukazatele efektivity trhu. Tento mikroekonomický výzkum by měl určovat jak cenové rozdíly mezi nabídkovými a realizovanými cenami, tak i dobu trvání prodeje každé entity vybraného trhu a segmentu. Výzkum zahrnuje dva segmenty trhu s nemovitostmi v České republice: rodinné domy a zemědělské pozemky. Data jsou kontinuálně shromažd’ována od března 2017. Aktualizována jsou jednou týdně, aby bylo možné určit dobu trvání nabídky, nabídkovou cenu a realizovanou (tržní) cenu. Údaje o realizovaných cenách byly získány z katastru nemovitostí. Dílčí výsledky tohoto výzkumu jsou uplatnitelné jako vstupy do komparativní metody ocenění.
\end{abstract}

Klícová slova: poptávková cena, realizovaná cena, doba trvání nabídky, nemovitost, porovnávací způsob.

\section{1. ÚVOD}

Při aplikaci komparativního přístupu ocenění je zásadní relevantní databáze srovnávaných nemovitých věcí. Pro ocenění je možné použít dva typy srovnávacích nemovitých věcí, a to bud' nabídkových cen z realitní inzerce, nebo cen realizovaných, tedy skutečných prodejních cen. Jak uvádí profesor Bradáč: „Dosahované ceny nemovitostí jsou dỉležitým podkladem pro cenové porovnání. “ [2] [6] Dosahované neboli tržní ceny byly pro výzkum prezentovaný v článku získány z katastru nemovitostí, a to na základě podpory vysokoškolského specifického výzkumu VUT. Pokud jsou nabídkové ceny zdrojem pro porovnávací způsob ocenění, je nutné odhadnout rozdíl mezi nabídkovou a realizovanou cenou $\mathrm{I}_{\Delta \mathrm{P}}(\mathrm{v}$ českém prostředí a terminologii je tento pojem užíván také jako koeficient redukce na zdroj ceny).

\begin{abstract}
The article deals with the monitoring of asking price development till realizing a market transaction as the indicator of the market efficiency. Such microeconomics research should determine both the price differences and the duration of the time it takes to sell each entity of selected market and segment.

The research comprises two real estate market segments in the Czech Republic: family houses and agricultural lands. The data have been being collected since March 2017 and being updated once a week to determine the duration of offering, asking price and market price. Particular transactions with details were provided by the Land Register. Particular results of this research are applicable as inputs to the sale comparison approach.
\end{abstract}

Keywords: asking price, duration, market price, real estate, sales comparison approach.

\section{TEORETICKÉ VYMEZENÍ}

Problém nabídkových cen u nemovitostí je poměrně sofistikovaný a špatně identifikovatelný z důvodů různých strategií prodejců nebo jejich zástupců. Může se vyskytovat takzvaný overpricing (iniciační nabídková cena je př́liš vysoká), jako efekt, který ovlivňuje prodávající [1] nebo opětovné „,vyvěšováni““ nabídky, jako možnost měnícího se vnímání cenových informací [7].

U dlouhé doby trvání nabídky má prodávající tedy v podstatě tři možnosti. První je nadále udržovat iniciační nabídkovou cenu (prodávající tedy nemůže na prodej nemovitosti spěchat/naléhat). Druhou variantou je snížit nabídkovou cenou (někdy opětovně snižovat), poslední možností je opětovné vyvěšení nabídky tedy stáhnutí nabídky z inzerce a znovu obnovení s jinou nebo obdobnou cenou. 


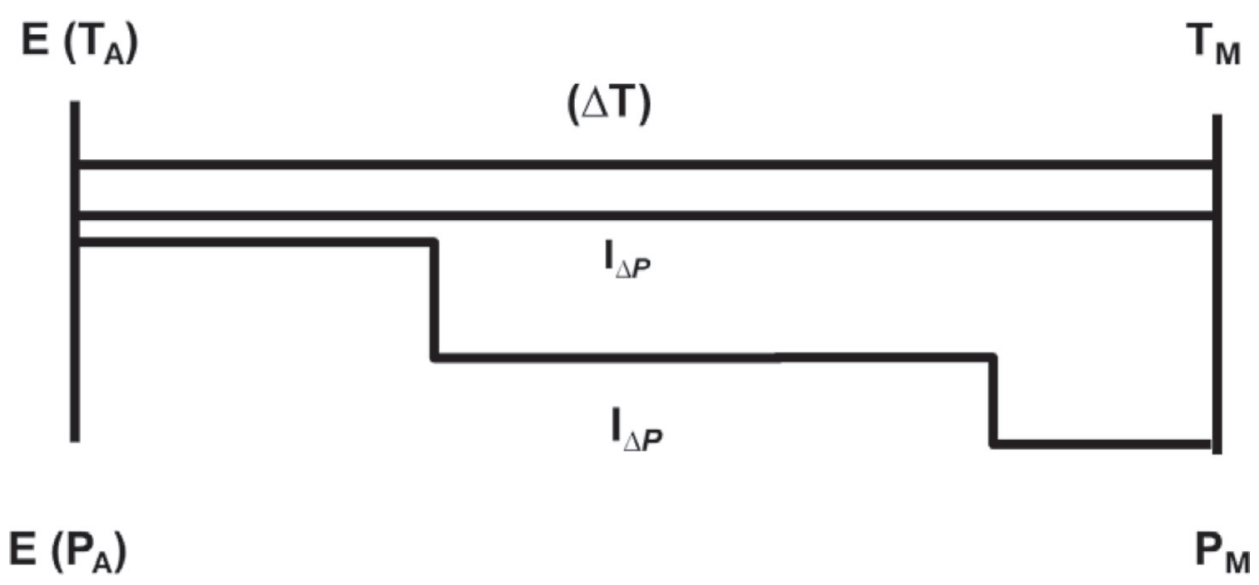

Obr. 1 Schéma zkoumaných charakteristik [Zdroj: vlastní].

Fig. 1 Scheme of examined characteristics.

Mikroekonomický výzkum, který zahrnuje sledování vývoje nabídkové ceny až do realizace tržní transakce, jako ukazatele efektivity trhu, by měl být definován hlavními dvěma charakteristikami, a to jak cenovým rozdílem (mezi nabídkovou a prodejní cenou), tak dobou trvání prodeje při individuálním sledování vybraného trhu a jeho segmentu. Proto je nutné sledovat tyto dvě závislé proměnné $\Delta P$ a $\Delta T$ (likvidnost). Definice je

$$
I_{\Delta P}=P_{M} / E\left(P_{A}\right),
$$

vyjadřuje rozdíl mezi prodejní cenou a nabídkovou cenou a

$$
\Delta T=T_{M}-E\left(T_{A}\right)
$$

vyjadřuje dobu prodeje, oba pro individuální nemovitosti. $P_{M}$ (market price) je prodejní cena s jednoznačným prodejním časem (datum podání návrhu na vklad do katastru nemovitostí). Střední hodnota očekávaná $P_{A}$ (asking price, nebo také list price) by měl být zatížen tak malým rozptylem, jak je to jen možné stejně jako odhad $T_{A}$. Jelikož jsou obě proměnné relevantní pro jeden objekt, $\mathrm{v}$ podstatě se jedná o náhodnou veličinu $\mathrm{z}$ dvourozměrného rozdělení [4]. Ve skutečnosti je zapotřebí dokonale sledovat trh $\mathrm{s}$ cílem identifikovat objekt s oběma daty $\left(T_{M}, T_{A}\right)$.

Hlavně proměnná $I_{\Delta P}$ je vhodná k provedení korekce mezi nabídkovou cenou a realizovanou cenou.

\section{METODOLOGIE A DATA}

V rámci tohoto výzkumu byla aplikovaná metoda mikroanalýzy, a to na dvou databázích, respektive pro dva segmenty realitního trhu. Prvním typem byly rodinné domy a druhým zemědělské nemovitosti.

Rodinné domy byly monitorovány v okrese Brno - venkov. Zemědělské pozemky byly sledovány na větším území, a to celkem

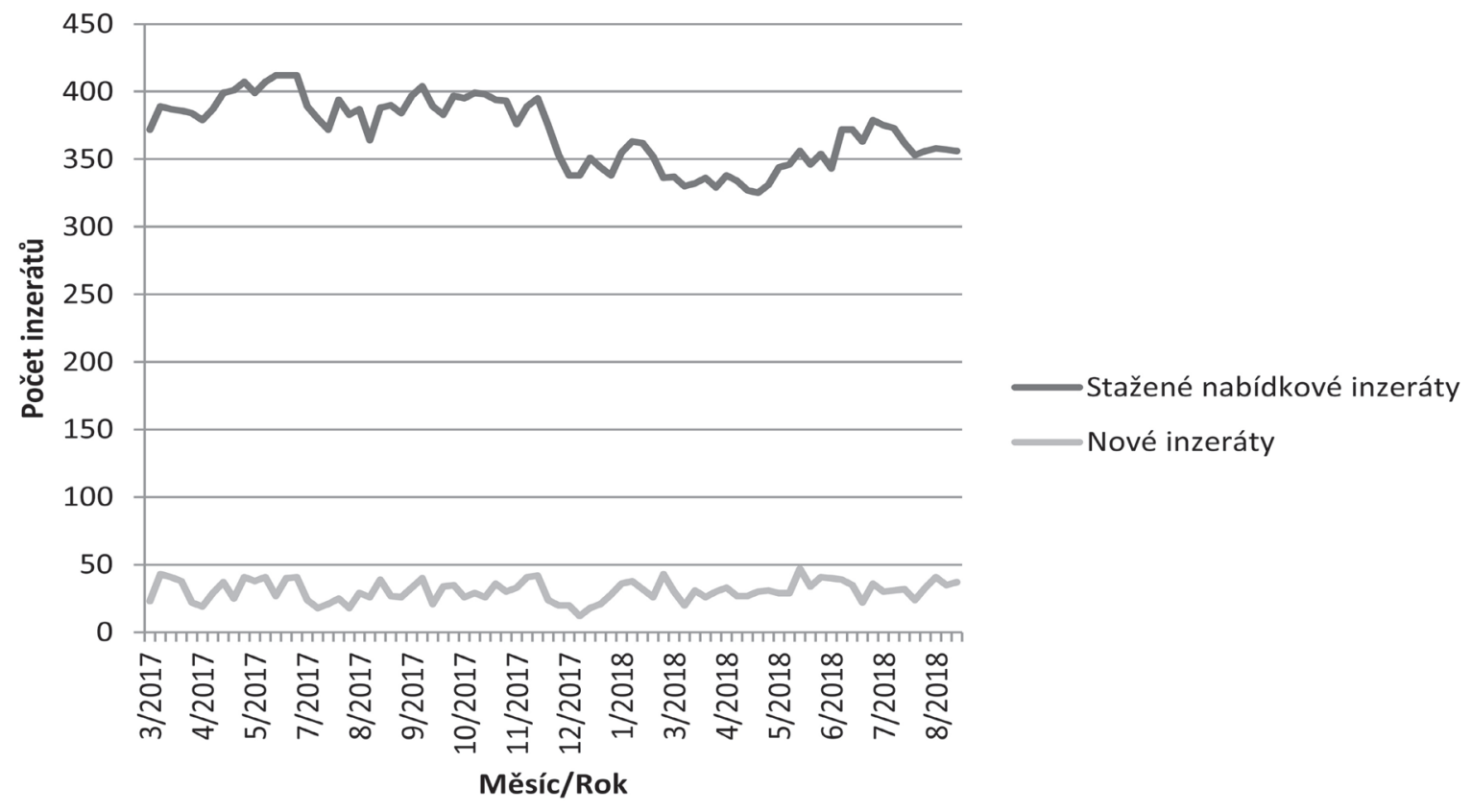

Obr. 2 Počty inzerátů v průběhu doby trvání mikroekonomického výzkumu.

Fig. 2 Number of ads during the microeconomic research period. 
v 11 okresech a dvou krajích České republiky, v kraji Vysočina a Jihomoravském. Ani jeden typ entity nebyl sledován v okrese Brno-město. Zemědělské pozemky se $\mathrm{v}$ tomto okrese prakticky nevyskytují a u rodinných domu je doba mezi nabídkou a realizací velmi krátká, tudíž by nebylo časově možné průběžně dohledávat $\mathrm{k}$ jednotlivým entitám informace $\mathrm{z}$ katastru nemovitostí.

\subsection{Data získaná z realitní inzerce}

Zdrojem pro nabídkovou databázi byla realitní inzerce. Data získaná $\mathrm{z}$ inzerce byla průběžně v čase aktualizovaná, vždy jednou týdně v rozmezí od 12. 3. 2017 do 9. 9. 2018, tedy rok a půl. Sběr dat nadále probíhá.

Celkem bylo $\mathrm{v}$ této fázi a $\mathrm{v}$ tomto časovém rozmezí sledováno 2790 rodinných domů a 3069 zemědělských nemovitostí. V tak objemných databázích však nebylo možné postihnout všechny duplicitní či konkurenční nabídky.

Graf na obr. 1 zobrazuje počet stažených inzerátů s rodinnými domy za každý týden. Jedná se o všechny nabídkové inzeráty (vyznačeny tmavě). Světle šedou barvou jsou znázorněny nově nabízené rodinné domy, tj. nový přírůstek nabídky v inzerci.

\subsection{Identifikace entit $v$ katastru nemovitostí}

Pro získání cenových údajů z katastru nemovitostí bylo nejdříve nutné dostatečně identifikovat předmět nabídky. Jednotlivé nabídky z realitních inzercí byly průběžně procházeny a byly $\mathrm{k}$ nim dohledávány potřebné informace $\mathrm{z}$ katastru nemovitostí.

U zemědělských pozemků byla dohledávána parcelní čísla, katastrální území, GPS, druh pozemku a velikost vlastnického podílu.

Mezi zemědělské pozemky byly řazeny pozemky evidované v katastru nemovitostí v druhu pozemku trvalý travný porost a orná půda. V nabídkách realitních inzercí však byly zemědělské nemovitosti složeny často $\mathrm{z}$ více druhů pozemků, vyskytovaly se zde ostatní a vodní plochy či lesní pozemky. Tyto pozemky byly $\mathrm{v}$ souboru ponechány $\mathrm{z}$ toho důvodu, že byly nabízeny většinou v souborech pozemků, nikoli samostatně.

U rodinných domů bylo evidováno opět katastrální území, parcelní číslo všech dotčených nemovitých věcí, GPS a adresa, kde se předmětný dům nachází. U rodinných domů byly nalezeny i identifikátory $\mathrm{k}$ dalším stavbám a pozemkům náležejícím ke stavbě hlavní, a to např. garáže.

U rodinných domů bylo z celkového počtu nabídek 2790 identifikováno v katastru nemovitostí 611 nemovitostí. U zemědělských pozemků z celkového počtu 3069 bylo v tomtéž veřejném seznamu identifikováno 662 nabídek.

Počet entit, u kterých nebyly nalezeny potřebné informace v katastru nemovitostí, je násobně větší. Prvním a nejčastějším důvodem, proč k entitám nebyly dohledány informace, byla doba nabídky v inzerci. Dř́ve než se podařilo najít identifikační údaje, byly tyto nabídky z inzerce smazány. Pokud byly nemovité věci nabízeny formou dražby, at' již dobrovolné nebo nucené, byly z databází také vyloučeny. Dalším důvodem byl jednoznačný nedostatek informací v jednotlivých inzerovaných nabídkách, případně nabídka nedisponovala dostatkem informací potřebných pro identifikování nemovité věci v katastru nemovitostí. Důvodem pro vyloučení $\mathrm{z}$ databáze byla také absence ceny $\mathrm{v}$ daném inzerátu. V jednotlivých inzercích se také objevovaly chyby, nabízeny byly pozemky se špatně uvedeným katastrálním územím, obcí či okresem. U rodinných domů byly vyřazeny také developerské projekty, které formou jednoho inzerátu nabízejí více nedokončených staveb. Zahrnuty nebyly také hrubé stavy, administrativní budovy, výrobní areál, ubytovací zařízení, chaty, vinné sklepy či objekty mlýna, prodeje pouze ideální poloviny domu či rodinné domy, kde byl nabízen pouze projekt a pozemek. U zemědělských pozemků nebyly obdobně zařazeny nabídky popsané výše. Vyřazeny byly takové pozemky, které byly sice nabízeny jako zemědělské, ale byla na nich jakákoliv stavba. Jednalo se převážně o chaty, vinné sklepy, studny, skleníky a jiné.

\subsection{Cenová údaje $\mathrm{z}$ katastru nemovitostí}

Nabídky, které byly vzaty do výzkumu, byly nadále průběžně sledovány a evidovány až do data vymazaní z inzerce. U těchto entit bylo na začátku zář́ ověřeno, zda-li je v katastru nemovitostí evidován cenový údaj.

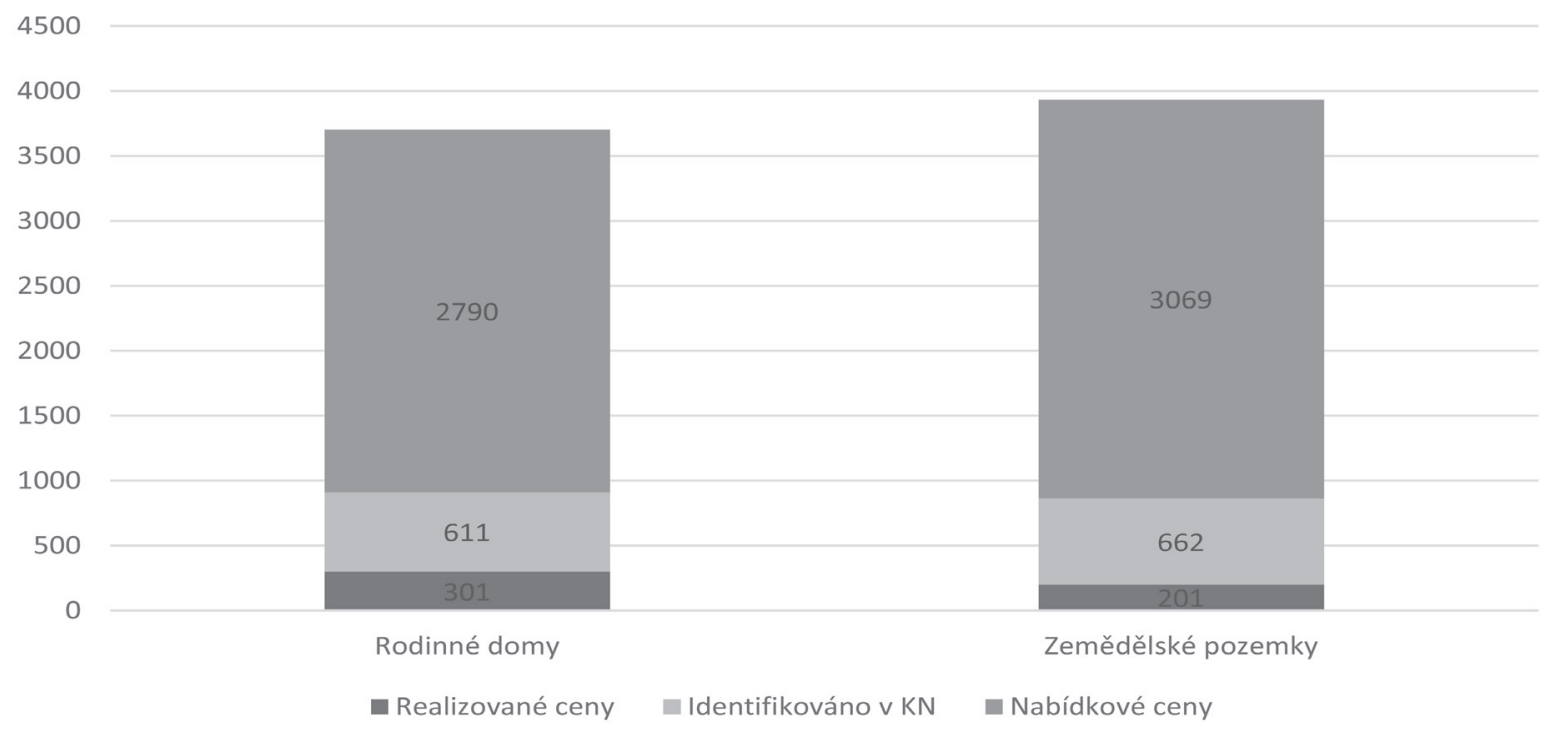

Obr. 3 Počet vzorků v jednotlivých databázích.

Fig. 3 Number of samples in individual databases. 
Celorepublikově vede cenové údaje katastr nemovitostí. Tato instituce zveřejňuje informace o cenových údajích od novely občanského zákoníku č. 89/2012 Sb. a katastrálního zákona č. 253/2013 Sb., respektive od data účinnosti těchto předpisů k 1. 1. 2014. [6] A to k zcizení, nikoli však pro nájem či pacht. Cenové údaje eviduje k těmto nemovitým věcem, parcele, stavbě, jednotce či právu stavby.

U tohoto výzkumu byly cenové údaje žádány na základě řizení a nebyly dožadovány kopie ze sbírky listin. Což činilo problém při identifikaci prodeje podílu, zejména u zemědělských pozemků.

Začátkem ř́ijna 2018 byly z katastru nemovitostí vyžádány cenové údaje. Celkem bylo pro výzkum k 9. 9. 2018 získáno relevantních 301 rodinných domů a 201 zemědělských pozemků. Konkrétní nabídka je vždy spojena s realizovanou cenou.

\subsection{Výsledky pozorování}

Graf na obr. 3 ukazuje počet vzorků v jednotlivých fázích výzkumu k zárí roku 2018. Jak je patrné, počet dat v nabídkové databázi převyšuje data v obou následujících databázích.

Jako indikátor prodejnosti nemovitých věcí lze považovat dobu trvání nabídky $\Delta \mathrm{T}$, a především koeficient redukce na zdroj ceny $k_{c z}$ [4], který je totožný s indikátorem $I_{\Delta P}$. Tyto charakteristiky variability byly sledovány $\mathrm{v}$ jednotlivých okresech u zemědělských pozemků. Výsledky zobrazuje tab. 1 .

Jeden z nejnižších $I_{\Delta P}$ je v okrese Jihlava, kde dosahuje rozdílu mezi nabídkovou a prodejní cenou pouhých $9 \%$. Výběrová směrodatná odchylka dosahuje pouze 0,08 a taktéž i doba trvání nabídky $\Delta T$ je druhá nejkratší. To vše je však způsobeno pouhými pěti vzorky. Největší počet realizovaných prodejů je však zaznamenán v okrese Brno - venkov, což potvrzuje výběr tohoto okresu i pro realizaci výzkumu rodinných domů právě v tomto okrese.

Tab. 2 uvádí souhrnné statistiky obou klíčových proměnných pro rodinné domy v okrese Brno - venkov a pro všechny zemědělské pozemky v Jihomoravském kraji a na Vysočině.

Průměr $I \Delta P$ vyšel u obou druhů nemovitostí velmi podobně, a to 0,89 pro rodinné domy a 0,86 pro zemědělské pozemky. Průměr u doby trvání nabídky však je delší u rodinných domů o celých 67 dní.

Nedávná výzkumná studie Gordon a Winkler se také zabývala dobou trvání nabídky a jednotlivými faktory, které ovlivňují změnu ceny v průběhu trvání nabídky. Následným krokem tohoto výzkumu bude právě hodnocení jednotlivých faktorů, které se podílejí na změně těchto indikátorů likvidnosti. Pro statisticky významné hodnocení je však nutné zvětšit rozsah datového souboru realizovaných cen. [5]

\section{ZÁVĚR}

Cílem tohoto mikroekonomického výzkumu bylo analyzovat a vyhodnotit cenová data $\mathrm{z}$ realitních serverů a data získána

Tab. 1 Rozdíly mezi nabízenými a tržními cenami u zemédělských pozemků.

Tab. 1 Differences between asking and market prices for agricultural land.

\begin{tabular}{lccccrc}
\hline \multirow{2}{*}{ Okres } & \multicolumn{2}{c}{ Pozorování } & \multicolumn{2}{c}{$\boldsymbol{I \Delta P}$} & \multicolumn{2}{c}{$\boldsymbol{\Delta}$} \\
\cline { 2 - 7 } & $\begin{array}{l}\text { Vzorky } \\
\text { celkem }\end{array}$ & Prodané & Průměr & $\begin{array}{c}\text { Směrodatná } \\
\text { odchylka }\end{array}$ & Průměr & $\begin{array}{c}\text { Směrodatná } \\
\text { odchylka }\end{array}$ \\
\hline Blansko & \multicolumn{2}{c}{ Zemědělské pozemky } \\
Brno - venkov & 261 & 23 & 0,86 & 0,22 & 89 & 71,9 \\
Břeclav & 603 & 31 & 0,82 & 0,29 & 109 & 95,4 \\
Hodonín & 462 & 15 & 0,85 & 0,18 & 101 & 121,2 \\
Vyškov & 576 & 30 & 0,86 & 0,20 & 133 & 94,9 \\
Znojmo & 207 & 13 & 0,81 & 0,29 & 48 & 54,7 \\
Havlíčkův Brod & 274 & 18 & 0,89 & 0,25 & 156 & 130,8 \\
Jihlava & 152 & 12 & 0,86 & 0,24 & 86 & 78,6 \\
Pelhřimov & 61 & 5 & 0,91 & 0,08 & 54 & 50,5 \\
Třebíč & 134 & 17 & 0,91 & 0,11 & 101 & 87,2 \\
Žd'ár nad Sázavou & 139 & 13 & 0,82 & 0,30 & 72 & 63,3 \\
\hline
\end{tabular}

Tab. 2 Rozdíly mezi nabizenými a tržními cenami souhrn.

Tab. 2 Differences between asking and market prices summary.

\begin{tabular}{|c|c|c|c|c|c|c|}
\hline \multirow[t]{2}{*}{ Okres } & \multicolumn{2}{|c|}{ Pozorování } & \multicolumn{2}{|c|}{$I \Delta P$} & \multicolumn{2}{|c|}{$\Delta T$} \\
\hline & $\begin{array}{l}\text { Vzorky } \\
\text { celkem }\end{array}$ & Prodané & Průměr & $\begin{array}{c}\text { Směrodatná } \\
\text { odchylka }\end{array}$ & Průměr & $\begin{array}{c}\text { Směrodatná } \\
\text { odchylka }\end{array}$ \\
\hline \multicolumn{7}{|c|}{ Zemědělské pozemky } \\
\hline Souhrn & 3069 & 201 & 0,86 & 0,22 & 104 & 92,8 \\
\hline \multicolumn{7}{|c|}{ Rodinné domy } \\
\hline Brno - venkov & 2790 & 301 & 0,89 & 0,13 & 171 & 99,8 \\
\hline
\end{tabular}


z katastru nemovitostí. Výsledky mohou být využity při oceňování komparativním způsobem v České republice, a to u předmětných nemovitostí a ve vybraných okresech.

Tento příspěvek vznikl v rámci projektu specifického výzkumu s názvem: „Sledování vývoje cen nemovitostí od nabídky do uskutečnění transakce na mikroekonomické úrovni a ověření diferencí v rámci porovnávacího způsobu ocenění různými odhadci“, ÚSI-J-17-4664.

\section{LITERATURA}

[1] ANDERSON, R. I., BRASTOW, R. T., TURNBULL, G. K., WALLER, B. D. Seller Over-Pricing and Listing Contract Length: The Effects of Endogenous Listing Contracts on Housing Markets. Journal of Real Estate Finance and Economics, 49(3), 434-450.

[2] BRADÁČ, A. a kol. Teorie a praxe oceňování nemovitých věcí, 1. Vydání. CERM, Brno, 2016, 790 s. ISBN 978-80-7204-930-1.
[3] CUPAL, M. Vztah nabídkových cen obytných nemovitostí a jejich odpovídajících dob trvání nabídky. Soudní inženýrství, ročník 20(4), s. 188-195. ISSN 1211-443X.

[4] CUPAL, M. Bid prices and market prices relation of real estates modelling. Journal of International Scientific Publications: Economy \& Business, 2010, roč. 2010, č. 4, s. 213-220. ISSN 1313-2555.

[5] GORDON, B. L., WINKLER, D. T. 2017. The Effect of Listing Price Changes on the Selling Price of Single-Family Residential Homes. Journal of Real Estate Finance and Economics, 55(2), 185-215.

[6] OPÁLKOVA, Tereza. Cenové podklady z katastru nemovitostí jako podklad pro ocenéní porovnávacím zpuisobem. In Sborník př́spěvků konference Junior Forensic Science Brno 2017. Brno: Vysoké učení technické v Brně, Ústav soudního inženýrství, 2017. s. 201-208. ISBN 978-80-214-5486-6.

[7] SMITH, P. S., GIBLER, K. M., ZAHIROVIC-HERBERT, V. 2016. The Effect of Relisting on House Selling Price. Journal of Real Estate Finance and Economics, 52(2), 176-195.

\section{Správná citace:}

OPÁlKOVÁ, T., CUPAL, M. Vývoj cen nemovitostí od nabídky do uskutečnění transakce. Soudní inženýrství, 2019, 30(1), 9-13. DOI: http://dx.doi.org./10.13164/SI.2019.1.9. ISSN 1211-443X. 